\title{
氧化铅在氨基甲酸乙酯与乙醇合成碳酸二乙酯反应中的催化作用
}

\author{
郭莲, 赵新强", 安华良, 王延吉 \\ 河北工业大学绿色化工与高效节能河北省重点实验室, 天津 300130
}

摘要: 研究了氧化铅在氨基甲酸乙酯 (EC) 与乙醇反应合成碳酸二乙酯 (DEC) 中的催化作用. 结果表明, 氧化铅具有很好的稳 定性, 重复使用 5 次, 其催化活性无明显下降. 回收的催化剂为立方晶相金属 $\mathrm{Pb}$ 和斜方晶相 $\mathrm{PbO}_{2}$ 的混合物, 结合反应结果可 认为, 该混合物为反应的活性组分. 结果还发现, $\mathrm{PbO}$ 与 $\mathrm{DEC}$ 反应是 $\mathrm{PbO}$ 被还原为 $\mathrm{Pb}$ 的主要原因.

关键词: 碳酸二乙酯; 氨基甲酸乙酯; 氧化铅; 乙醇; 尿素

中图分类号: 0643.3 文献标识码: A

收稿日期: 2011-11-06. 接受日期: 2011-12-20.

*通讯联系人. 电话: (022)60202427; 传真: (022)60204294; 电子信箱: zhaoxq@hebut.edu.cn

基金来源：973 计划前期研究专项 (2010CB234602); 国家自然科学基金 (20976035, 21076059); 河北省自然科学基金 (B2010000019).

本文的英文电子版(国际版)由Elsevier出版社在ScienceDirect上出版(http://www.sciencedirect.com/science/journal/18722067).

\section{Catalysis by Lead Oxide for Diethyl Carbonate Synthesis from Ethyl Carbamate and Ethanol}

\author{
GUO Lian, ZHAO Xinqiang*, AN Hualiang, WANG Yanji \\ Hebei Provincial Key Lab of Green Chemical Technology and High Efficient Energy Saving, Hebei University of Technology, \\ Tianjin 300130, China
}

\begin{abstract}
The catalysis by lead oxide in the reaction of ethyl carbamate (EC) with ethanol to form diethyl carbonate (DEC) was studied. The lead oxide catalyst exhibited an excellent stability, which could be reused five times without a significant loss in catalytic activity. X-Ray powder diffraction analysis showed that the recovered catalyst was a mixture of cubic metal $\mathrm{Pb}$ and orthorhombic $\mathrm{PbO}_{2}$, with the latter shown to be the real active component for the synthesis of DEC. Verification experiments showed that the reaction between $\mathrm{DEC}$ and $\mathrm{PbO}$ was the main reason for the reduction of $\mathrm{PbO}$ to metal $\mathrm{Pb}$.
\end{abstract}

Key words: diethyl carbonate; ethyl carbamate; lead oxide; ethanol; urea

Received 6 November 2011. Accepted 20 December 2011.

*Corresponding author. Tel: +86-22-60202427; Fax:+86-22-60204294; E-mail: zhaoxq@hebut.edu.cn

The work was supported by the Special Program for Basic Research Program of the Ministry of Science and Technology of China (2010CB234602), the National Natural Science Foundation of China (20976035, 21076059), and the Natural Science Foundation of Hebei province (B2010000019).

English edition available online at Elsevier ScienceDirect (http://www.sciencedirect.com/science/journal/18722067).

碳酸二乙酯 $(D E C)$ 不仅是重要的有机中间体, 而且可以广泛用作燃料添加剂. DEC 的合成方法主 要有光气法、酯交换法、乙醇氧化羰基化法、 $\mathrm{CO}_{2}$ 醇 解法和尿素醇解法等. 光气法原料有剧毒, 副产物 $\mathrm{HCl}$ 的腐蚀性强 ${ }^{[1]}$. 酯交换法受热力学限制, 平衡转 化率低且原料来源受石油化工限制 ${ }^{[2,3]}$. 乙醇氧化羰
基化法单程转化率低, 催化剂价格高且稳定性 差 ${ }^{[4 \sim 8]} . \mathrm{CO}_{2}$ 醇解法属于热力学不利的反应, 尚处于 基础研究阶段 ${ }^{[9]}$. 尿素醇解法是合成 DEC 的新方 法, 以尿素为羰基化试剂, 原料来源广泛, 产物分离 操作简单 ${ }^{[10]}$.

在尿素醇解法合成碳酸酯反应中, 首先尿素与 
醇反应生成中间物氨基甲酸酯, 后者继续醇解生成 碳酸酯. 即使不用催化剂, 第一步反应也很快, 且选 择性较高, 而第二步反应比较困难, 为反应的控制步 骤, 因此研究第二步反应具有重要意义. Zhao 等 ${ }^{[11]}$ 考察了锌类化合物在氨基甲酸甲酯 $(\mathrm{MC})$ 与甲醇合 成碳酸二甲酯 (DMC) 反应中的催化活性, 发现 $\mathrm{ZnCl}_{2}$ 的催化活性最好, DMC 的最高收率为 $33.6 \%$. 均相金属盐催化剂活性虽高, 但分离回收困难, 因而 非均相催化剂广受关注. $\mathrm{Wu}$ 等 ${ }^{[12]}$ 制备了一系列锌 基催化剂, 用于 $\mathrm{DMC}$ 合成反应, 其收率为 $12.7 \%$. Wang 等 ${ }^{[13,14]}$ 评价了混合金属氧化物催化剂在 DMC 合成反应中的活性, 发现锌-铁氧化物的活性最好, $\mathrm{DMC}$ 收率为 $31.5 \%$. 比较而言, 有关 DEC 合成反应 的报道较少. Zhao 等 ${ }^{[15]}$ 发现, $\mathrm{CaO}$ 对氨基甲酸乙酯 (EC) 与乙醇合成 DEC 反应有较好的催化活性, $\mathrm{DEC}$ 收率为 $10.8 \%$.

本课题组曾考察了一系列金属氧化物在 $\mathrm{EC}$ 与 乙醇合成 DEC 反应中的催化性能, 发现氧化铅的最 好, 在适宜的反应条件下, DEC 的收率为 $16.2 \%^{[16]}$. 本文进一步研究氧化铅催化剂的重复使用性能及催 化作用.

将碳酸铅在空气中于 $300{ }^{\circ} \mathrm{C}$ 焙烧 $4 \mathrm{~h}$ 制得氧化 铅催化剂. DEC 合成反应在配有精馏柱的 $500 \mathrm{ml}$ 高压反应釜中进行, 用 $\mathrm{N}_{2}$ 将副产物 $\mathrm{NH}_{3}$ 带出, 采用 背压阀控制反应系统压力. 典型反应过程如下: 依 次将 $30.5 \mathrm{~g}$ DEC、 $158 \mathrm{~g}$ 乙醇和 $1.9 \mathrm{~g}$ 催化剂加入反 应釜; 用 $\mathrm{N}_{2}$ 置换反应釜内空气后, 将压力升至 2 $\mathrm{MPa}$; 在搅拌速率为 $400 \pm 50 \mathrm{r} / \mathrm{min}$ 条件下, 升至 $180{ }^{\circ} \mathrm{C}$ 进行反应; 反应结束冷却至室温后拆釜, 将 反应混合物称重、过滤后进行定量分析.

气相反应产物采用北京北分瑞利分析仪器有限 公司的 SP 3400 型气相色谱仪进行分析. 色谱柱 PLOT-Q, 柱温 $50^{\circ} \mathrm{C}, \mathrm{TCD}$ 检测器, 检测器温度 120 ${ }^{\circ} \mathrm{C}$, 气化室温度 $120{ }^{\circ} \mathrm{C}$. 液相反应产物采用北京北 分瑞利分析仪器有限公司的 SP 2100 型气相色谱仪 进行分析. 色谱柱 PEG-20M, 柱温采用程序升温控 制, 气化室温度 $200^{\circ} \mathrm{C}$, FID 检测器, 检测器温度 $220{ }^{\circ} \mathrm{C}$. 液相反应产物定性分析采用美国 Agilent 公 司的 6890/5973 型气相色谱-质谱 (GC-MS) 分析仪 进行, 色谱柱为 HP-INNOWax, 扫描范围 $m / z=$ 10 500 amu. 采用日本理学的 D/MAX-2500 型 X
射线衍射仪对样品的物相进行测定, $\mathrm{Cu} K_{\alpha}$ 射线, 工 作电压 $40 \mathrm{kV}$, 电流 $100 \mathrm{~mA}$, 扫描范围 $2 \theta=5^{\circ} \sim 90^{\circ}$.

将回收的氧化铅催化剂用乙醇洗涤, 并于 $80^{\circ} \mathrm{C}$ 真空干燥 $12 \mathrm{~h}$ 后, 用于下一次反应, 结果见表 1 . 可 以看出, 催化剂重复使用 5 次, DEC 的收率和选择 性基本保持不变, 说明该催化剂具有较好的重复使 用性能.

表 1 氧化铅催化剂的重复利用

Table 1 Reuse of lead oxide catalyst

\begin{tabular}{cccc}
\hline Run & EC conversion (\%) & DEC yield (\%) & DEC selectivity (\%) \\
\hline 1 & 36.5 & 15.7 & 43.0 \\
2 & 36.8 & 16.2 & 44.0 \\
3 & 37.0 & 16.1 & 43.5 \\
4 & 33.4 & 15.1 & 45.2 \\
5 & 36.7 & 16.4 & 44.7 \\
\hline
\end{tabular}

Reaction conditions: $n$ (ethanol): $n(\mathrm{EC})=10$, catalyst concentration 1 wt $\%, 180^{\circ} \mathrm{C}, 7 \mathrm{~h}, 2 \mathrm{MPa}$. EC-Ethyl carbamate; DEC—Diethyl carbonate.

为了确定反应前后催化剂的物相, 分别对新鲜 催化剂及使用 1 次、 3 次和 5 次后的催化剂进行了 XRD 分析, 结果见图 1. 可以看出, 新鲜催化剂中主 要含有四方晶相 $\mathrm{PbO}$ 和斜方晶相 $\mathrm{PbO}_{2}$, 而反应后 催化剂中主要含有立方晶相金属 $\mathrm{Pb}$ 和斜方晶相 $\mathrm{PbO}_{2}$. 鉴于回收催化剂具有高的催化活性, 推测立 方晶相金属 $\mathrm{Pb}$ 和斜方晶相 $\mathrm{PbO}_{2}$ 共同催化 $\mathrm{EC}$ 和乙 醇反应生成了 DEC.

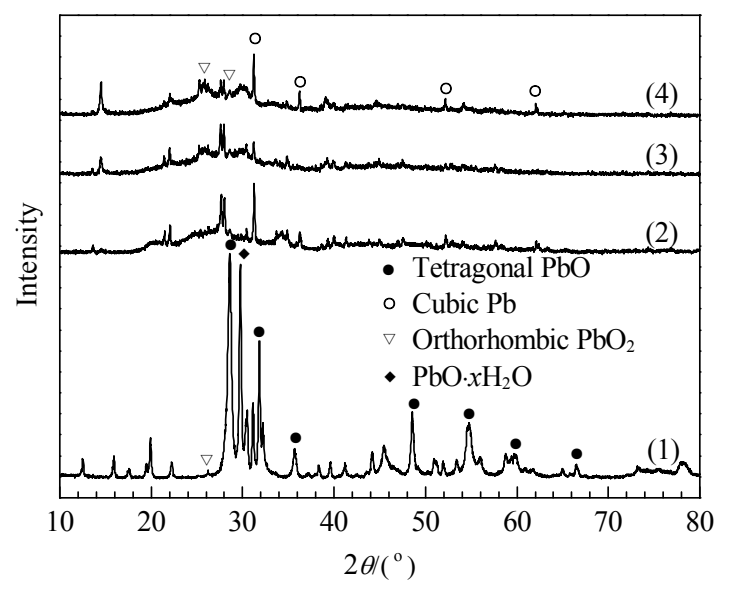

图 1 新鲜和回收氧化铅催化剂的 XRD 谱

Fig. 1. XRD patterns of the fresh and recovered lead oxide catalysts. (1) Fresh; (2) First recovered; (3) Third recovered; (4) Fifth recovered.

为了验证上述推论, 首先将氧化铅催化剂于管 式炉中在 $300{ }^{\circ} \mathrm{C}$ 用 $\mathrm{H}_{2}: \mathrm{N}_{2}$ 混合气 (体积比 $1: 1$ ) 还原 $6 \mathrm{~h}$ 制得金属铅催化剂, 其 XRD 谱见图 2. 可以看 


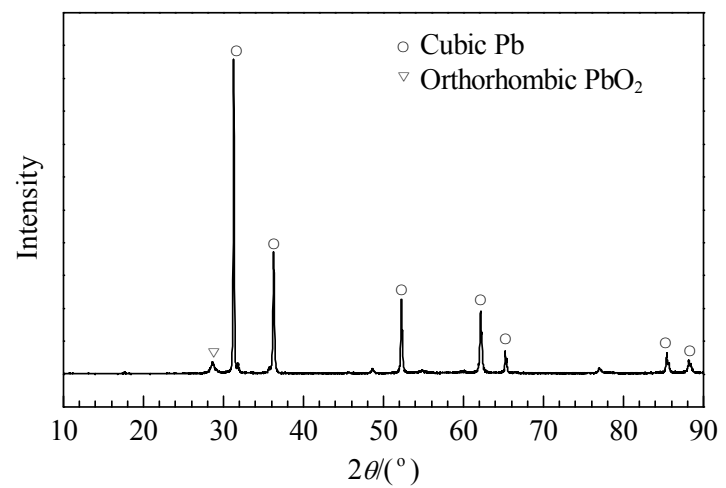

图 2 新鲜氧化铅催化剂还原产物的 XRD 谱

Fig. 2. XRD pattern of the sample prepared by reduction of the fresh lead oxide.

出, 还原后催化剂主要为立方晶相金属 $\mathrm{Pb}$ 和斜方晶 相 $\mathrm{PbO}_{2}$. 与图 1 中催化剂相比, 还原后催化剂中仅 出现 $\mathrm{PbO}_{2}(111)$ 晶面衍射峰. 这可能是由于两者所 处环境不同所致. 表 2 为纯金属 $\mathrm{Pb} 、 \mathrm{PbO}_{2}$ 和氧化铅 还原得到的金属铅上 EC 与乙醇合成 DEC 反应结 果. 由表可见, 纯金属 $\mathrm{Pb}$ 的催化活性比与新鲜 $\mathrm{PbO}$ 的相比很弱. 当以 $\mathrm{PbO}_{2}$ 为催化剂时, $\mathrm{DEC}$ 选择性与 以新鲜 $\mathrm{PbO}$ 为催化剂时比明显降低; 而制备的金属 铅催化剂具有较好的催化活性, DEC 收率相比以新 鲜氧化铅为催化剂时略低, 但其选择性更高, 为 $49.8 \%$. 鉴于制备的金属铅催化剂中主要含有金属 $\mathrm{Pb}$ 和 $\mathrm{PbO}_{2}$, 当以纯金属 $\mathrm{Pb}$ 和 $\mathrm{PbO}_{2}$ 的混合物 (质量 比 $=1: 1$ ) 为催化剂时, DEC 收率和选择性分别为 $13.9 \%$ 和 $41.9 \%$, 与新鲜氧化铅催化剂的接近. 由此 推测, 立方晶相金属 $\mathrm{Pb}$ 和斜方晶相 $\mathrm{PbO}_{2}$ 为催化活 性组分, 且两者的协同作用是其具有较高催化活性 的主要原因.

表 2 不同催化剂的催化性能

Table 2 Catalytic activity of different catalysts

\begin{tabular}{lccc}
\hline Catalyst & $\begin{array}{c}\text { EC conversion } \\
(\%)\end{array}$ & $\begin{array}{c}\text { DEC yield } \\
(\%)\end{array}$ & $\begin{array}{c}\text { DEC selectivity } \\
(\%)\end{array}$ \\
\hline Pure metal $\mathrm{Pb}$ & 12.1 & 1.9 & 15.7 \\
$\mathrm{PbO}_{2}$ & 34.6 & 11.3 & 32.7 \\
Metal lead sample $^{*}$ & 26.9 & 13.4 & 49.8 \\
$\mathrm{~Pb}+\mathrm{PbO}_{2}$ & 33.2 & 13.9 & 41.9 \\
Fresh lead oxide & 36.5 & 15.7 & 43.0 \\
\hline
\end{tabular}

"Prepared by reducing lead oxide.

Reaction conditions: $n$ (ethanol): $n(\mathrm{EC})=10$, catalyst concentration 1 $\mathrm{wt} \%, 180^{\circ} \mathrm{C}, 7 \mathrm{~h}, 2 \mathrm{MPa}$.

本文设计下列实验, 分析反应过程中催化剂组
分 $\mathrm{PbO}$ 被还原为金属 $\mathrm{Pb}$ 的原因.

实验 1: 乙醇与氧化铅 (乙醇与氧化铅质量比 为 $60: 1)$ 于 $180^{\circ} \mathrm{C}$ 反应 $7 \mathrm{~h}$. 液样中含有乙醛和乙 酸乙酯, 与 Idriss 等 ${ }^{[17]}$ 的研究结果一致. 推测乙醇 脱氢形成乙醛, 乙醛发生 Tishchenko 反应生成乙酸 乙酯. 反应后固样 XRD 结果表明, 样品中未出现金 属 $\mathrm{Pb}$ 的特征峰, 说明乙醇不能使 $\mathrm{PbO}$ 还原.

实验 2: $\mathrm{EC}$ 与氧化铅反应 (反应条件：水为溶 剂, $\mathrm{EC}$ 与氧化铅质量比为 $15: 1,180^{\circ} \mathrm{C}, 7 \mathrm{~h}$ ), 反应后 固样 XRD 谱中无金属 $\mathrm{Pb}$ 特征峰, 说明 $\mathrm{EC}$ 不能还 原 $\mathrm{PbO}$.

实验 3: DEC 与氧化铅反应 (反应条件: DEC 与氧化铅质量比为 $60: 1,180^{\circ} \mathrm{C}, 7 \mathrm{~h}$ ), 反应后固样 XRD 中检测到金属 $\mathrm{Pb}$ (见图 3), 说明 DEC 的存在 是导致 $\mathrm{PbO}$ 被还原的原因.

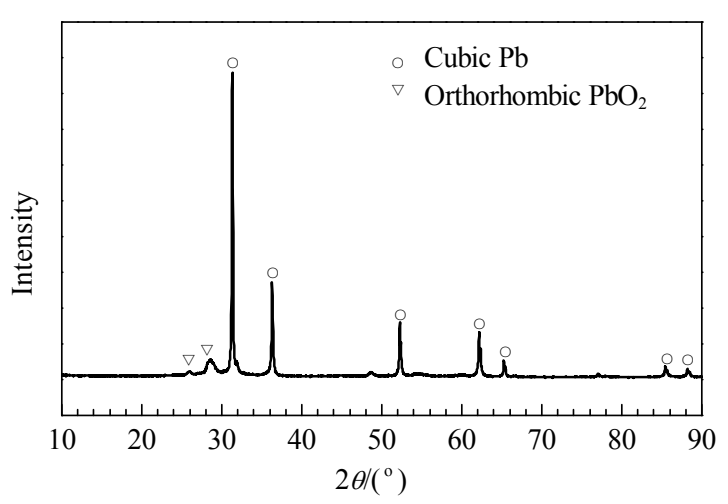

图 3 氧化铅与 DEC 反应后的 XRD 谱

Fig. 3. XRD pattern of lead oxide reacted with DEC.

为了进一步研究 DEC 与氧化铅的相互作用, 收 集 DEC 与氧化铅反应后的气相产物并进行分析, 发 现气相中含有 $\mathrm{H}_{2}, \mathrm{CO}_{2}$ 和 $\mathrm{C}_{2} \mathrm{H}_{4}$; 反应后液相产物的 GC-MS 结果发现, 反应液中除原料 DEC 外, 主要含 有乙醇、乙醚、乙酸乙酯和 $\mathrm{H}_{2} \mathrm{O}$ 等. 空白实验表明, $180^{\circ} \mathrm{C}$ 时 DEC 未发生分解. 文献[18]指出, DEC 在 $280 \sim 440{ }^{\circ} \mathrm{C}$ 时分解产生乙醇、 $\mathrm{C}_{2} \mathrm{H}_{4}$ 和 $\mathrm{CO}_{2}$, 而本文 在 $180^{\circ} \mathrm{C}$ 加入氧化铅后, DEC 发生了分解, 说明氧 化铅的存在促进了 DEC 的分解.

实验 4: 为了检验 DEC 与氧化铅的反应产物是 否可以还原 $\mathrm{PbO}$, 在 $\mathrm{CO}_{2}, \mathrm{H}_{2}, \mathrm{C}_{2} \mathrm{H}_{4}$ 和 $\mathrm{N}_{2}$ 的混合气 氛中, $\mathrm{PbO}$ 与含有乙醚、乙醛、乙酸乙酯和乙醇的液 相混合物反应 (反应条件: $\mathrm{PbO}$ 、乙醚、乙醛、乙酸 乙酯和乙醇的质量比为 $1: 1: 1: 1: 60,180^{\circ} \mathrm{C}, 7 \mathrm{~h}$ ), 反 
应后分析发现 $\mathrm{PbO}$ 未被还原为金属 $\mathrm{Pb}$. 说明上述 反应体系不能导致 $\mathrm{PbO}$ 的还原.

综上可见, $\mathrm{DEC}$ 与 $\mathrm{PbO}$ 之间的反应使得 $\mathrm{PbO}$ 被还原为金属 $\mathrm{Pb}$. 为了深入分析 $\mathrm{DEC}$ 与 $\mathrm{PbO}$ 之间 的反应, 设计了实验 5 (反应条件: DEC 与氧化铅质 量比为 $60: 1,180^{\circ} \mathrm{C}, 3 \mathrm{~h}$ ) 以考察反应时间对该反应 的影响. 当反应 $3 \mathrm{~h}$ 时, 分析发现反应液中含有乙 醛; 而设计实验 3 中当反应 $7 \mathrm{~h}$ 时, 反应液中未检测 到乙酫, 其余组分基本相同, 可见生成的乙醛继续反 应生成其它产物 ${ }^{[17]}$. 当反应至 $7 \mathrm{~h}$ 时, 反应体系中 DEC 含量减少, 乙醇含量增加, 说明延长反应时间, $\mathrm{DEC}$ 分解反应加剧. 因此推测 $\mathrm{DEC}$ 与 $\mathrm{PbO}$ 之间的 反应方程式如下:

$$
\begin{gathered}
\left(\mathrm{C}_{2} \mathrm{H}_{5} \mathrm{O}\right)_{2} \mathrm{CO}+\mathrm{PbO} \longrightarrow \\
\mathrm{C}_{2} \mathrm{H}_{4}+\mathrm{CH}_{3} \mathrm{CHO}+\mathrm{CO}_{2}+\mathrm{H}_{2} \mathrm{O}+\mathrm{Pb}
\end{gathered}
$$

此外, 该反应产物还有乙醇、乙醚、乙酸乙酯和 氢气. 结合前文可推测, DEC 分解生成乙醇 ${ }^{[18]}$, 乙 醇脱水生成乙醚 ${ }^{[19]}$; 乙醇脱氢生成乙酸乙酯和 $\mathrm{H}_{2}{ }^{[20]}$; 乙醛发生 Tishchenko 反应生成乙酸乙酯 ${ }^{[17]}$. 具体反应方程式如下所示:

$$
\begin{aligned}
&\left(\mathrm{C}_{2} \mathrm{H}_{5} \mathrm{O}\right)_{2} \mathrm{CO} \longrightarrow \mathrm{C}_{2} \mathrm{H}_{4}+\mathrm{C}_{2} \mathrm{H}_{5} \mathrm{OH}+\mathrm{CO}_{2} \\
& 2 \mathrm{C}_{2} \mathrm{H}_{5} \mathrm{OH} \longrightarrow \mathrm{C}_{2} \mathrm{H}_{5} \mathrm{OC}_{2} \mathrm{H}_{5}+\mathrm{H}_{2} \mathrm{O} \\
& 2 \mathrm{C}_{2} \mathrm{H}_{5} \mathrm{OH} \longrightarrow \mathrm{CH}_{3} \mathrm{COOC}_{2} \mathrm{H}_{5}+2 \mathrm{H}_{2} \\
& 2 \mathrm{CH}_{3} \mathrm{CHO} \longrightarrow \mathrm{CH}_{3} \mathrm{COOC}_{2} \mathrm{H}_{5}
\end{aligned}
$$

综上所述, 氧化铅催化剂在 DEC 合成反应中具 有较好的重复使用性能, 5 次后使用后其催化性能 未见明显下降, 立方晶相金属 $\mathrm{Pb}$ 和斜方晶相 $\mathrm{PbO}_{2}$ 为 $\mathrm{EC}$ 与乙醇反应的活性组分, 且两者间存在协同 作用. 验证实验表明, $\mathrm{PbO}$ 与 $\mathrm{DEC}$ 反应后还原为 $\mathrm{Pb} . \mathrm{Pb}$ 和 $\mathrm{PbO}_{2}$ 对 $\mathrm{EC}$ 与乙醇合成 $\mathrm{DEC}$ 反应的催化 机理有待于进一步研究.

\section{参 考 文 献}

1 Muskat I E, Strain F. US 2379 250. 1941

2 Frevel L K, Gilpin J A. US 3642 858. 1972

3 王默, 赵新强, 安华良, 王延吉. 高校化学工程学报 (Wang M, Zhao X Q, An H L, Wang Y J. J Chem Eng Chin Univ), 2010, 24: 663

4 Fenton D M. US 3227 740. 1966

5 Zhang P B, Huang S Y, Yang Y, Meng Q S, Wang S P, Ma X B. Catal Today, 2010, 149: 202

6 Zhu D J, Mei F M, Chen L J, Mo W L, Li T, Li G X. Fuel, 2011, 90: 2098
7 Zhang P B , Ma X B. Chem Eng J, 2010, 163: 93

8 马新宾, 黄守䒯, 王胜平, 张萍波. 石油化工 (Ma X B, Huang Sh Y, Wang Sh P, Zhang P B. Petrochem Technol), 2010, 39: 697

9 Gasc F, Thieloaud-Roux S, Moulougui Z. J Supercrit Fluids, 2009, 50: 46

10 Wang D P, Yang B L, Zhai X W, Zhou L G. Fuel Process Technol, 2007, 88: 807

11 Zhao W B, Wang F, Peng W C, Zhao N, Li J P, Xiao F K, Wei W, Sun Y H. Ind Eng Chem Res, 2008, 47: 5913

12 Wu C C, Zhao X Q, Wang Y J. Catal Commun, 2005, 6: 694

13 Wang D F, Zhang X L, Gao Y Y, Xiao F K, Wei W, Sun Y H. Catal Commun, 2010, 11: 430

14 Wang D F, Zhang X L, Zhao W B, Peng W C, Zhao N, Xiao F K, Wei W, Sun Y H. J Phys Chem Solids, 2010, 71: 427

15 Zhao W B, Peng W C, Wang D F, Zhao N, Li J P, Xiao F K, Wei W, Sun Y H. Catal Commun, 2009, 10: 655

16 赵海龙, 赵新强, 安华良, 王延吉. 石油化工 (Zhao H L, Zhao X Q, An H L, Wang Y J. Petrochem Technol), 2009, 38: 139

17 Idriss H, Seebauer E G. J Mol Catal, 2000, 152: 201

18 Notario R, Quijano J, Sánchez C, Vélez E. J Phys Org Chem, 2005, 18: 134

19 Varisli D, Dogu T, Dogu G. Chem Eng Sci, 2007, 62: 5349

20 Inui K, Kurabayashi T, Sato S, Ichikawa N. J Mol Catal, 2004, 216: 147

\section{英 译 文 \\ English Text}

Diethyl carbonate (DEC) is not only an important organic intermediate but also an attractive alternative oxygen-containing fuel additive. The DEC synthesis routes mainly include phosgenation of ethanol, transesterification of organic carbonates, oxidative carbonylation of ethanol, ethanolysis of $\mathrm{CO}_{2}$, and ethanolysis of urea. The phosgenation of ethanol is gradually being phased out because phosgene is highly toxic and the byproduct hydrogen chloride causes serious corrosion [1]. The transesterification of organic carbonates is thermodynamically governed. Moreover, the starting material (such as propylene oxide) is sourced from depleting petroleum reserves [2,3]. The oxidative carbonylation of ethanol suffers from low single-pass conversion, high catalyst costs, and poor stability [4-8]. The ethanolysis of $\mathrm{CO}_{2}$ is thermodynamically unfavorable and still in the stage of fundamental studies [9]. The ethanolysis of urea, however, is a potential route because it exhibits great advantages such as availability of raw materials and simple product separation [10].

The alcoholysis of urea can be divided into two steps: the synthesis of an intermediate alkyl carbamate from urea and an alcohol followed by reaction of the alkyl carbamate with 
the alcohol to form a dialkylcarbonate. The first step is fast and highly selective even without a catalyst, but the second step is more difficult [10]. Hence, it is important and necessary to study the second reaction. Zhao et al. [11] investigated the synthesis of dimethyl carbonate (DMC) from methyl carbamate (MC) and methanol over zinc compound catalysts. $\mathrm{ZnCl}_{2}$ showed the highest catalytic activity and led to a DMC yield of $33.6 \%$ under the optimal conditions. The homogeneous nature of the metal salts lead to separation and recovery problems. Since heterogeneous catalysis can overcome these drawbacks, this type of catalyst has attracted much more attention. Wu et al. [12] have prepared Zn-based catalysts, and the DMC yield obtained was $12.7 \%$ over zinc powder. Wang et al. $[13,14]$ investigated the catalytic performance of mixed oxide catalysts for the reaction for DMC synthesis, and zinc/iron mixed oxide possessed the best catalytic ability giving a DMC yield of $31.5 \%$. Compared with many studies on DMC synthesis, there were a few reports on DEC synthesis. Zhao et al. [15] found that $\mathrm{CaO}$ had good catalytic activity for the reaction of ethyl carbamate (EC) and ethanol to DEC, and the yield of DEC was $10.8 \%$.

In our previous work, lead oxide was found to be the most active catalyst for the reaction of EC and ethanol to DEC among a series of metal oxides studied, and the DEC yield was $16.2 \%$ [16]. Hence, a further study on the catalysis and reusability of lead oxide was carried out in this work. The reaction conditions in this work were identical to those described in our previous work [16].

Lead oxide was prepared by thermal decomposition of lead carbonate at $300{ }^{\circ} \mathrm{C}$ for $4 \mathrm{~h}$ in air. The DEC synthesis reaction was carried out in a $500 \mathrm{ml}$ stainless steel autoclave with a packed column and a back-pressure valve for ammonia gas removal. In a typical process, $30.5 \mathrm{~g} \mathrm{EC}, 158 \mathrm{~g}$ ethanol, and $1.9 \mathrm{~g}$ catalyst were introduced into the autoclave which was firstly purged with nitrogen and pressurized to 2 $\mathrm{MPa}$. After that, the reaction mixture was heated to $180{ }^{\circ} \mathrm{C}$ with stirring. After the completion of reaction, the autoclave was cooled to room temperature and the product mixture was weighed, filtered, and analyzed.

The gaseous products were analyzed on a SP 3400 gas chromatograph with a PLOT-Q packed column. The analysis conditions were as follows: $\mathrm{N}_{2}$ as carrier, TCD temperature $120^{\circ} \mathrm{C}$, the injection port temperature $120^{\circ} \mathrm{C}$, and column temperature $50^{\circ} \mathrm{C}$. The liquid products were analyzed on an SP 2100 gas chromatograph with a PEG-20M capillary column. The analysis conditions were as follows: $\mathrm{N}_{2}$ as carrier, FID temperature $220^{\circ} \mathrm{C}$, the injection port temperature $200{ }^{\circ} \mathrm{C}$, and the program-controlled column temperature. The reaction products were also qualitatively analyzed on a 6890/5973 GC-MS equipped with a HP-INNOWax column and mass spectra were obtained in a range of 10-500 amu. $\mathrm{X}$-ray diffraction (XRD) analysis of the catalyst was per- formed on a D/MAX-2500 diffractometer with $\mathrm{Cu} K_{\alpha}$ radiation, $40 \mathrm{kV}$ tube voltage, $100 \mathrm{~mA}$ tube electric current, and scanning range of $5^{\circ}$ to $90^{\circ}$.

First of all, the reusability of lead oxide catalyst was investigated. The used lead oxide catalyst was recovered by filtration, washed with ethanol, and dried at $80{ }^{\circ} \mathrm{C}$ for $12 \mathrm{~h}$ in vacuum. The activity evaluation shown in Table 1 reveals that both DEC yield and selectivity remained almost constant, indicating that lead oxide had high catalytic stability.

XRD patterns of the fresh, first recovered, third recovered, and fifth recovered lead oxide catalyst are shown in Fig. 1. Tetragonal $\mathrm{PbO}$ and orthorhombic $\mathrm{PbO}_{2}$ were observed in the fresh catalyst while cubic metal $\mathrm{Pb}$ and orthorhombic $\mathrm{PbO}_{2}$ appeared in the recovered catalyst. This suggested that tetragonal $\mathrm{PbO}$ had been transformed into cubic metal $\mathrm{Pb}$ during the reaction. Furthermore, we assumed that both cubic metal $\mathrm{Pb}$ and orthorhombic $\mathrm{PbO}_{2}$ catalyze the reaction for DEC synthesis from EC and ethanol because the catalytic composition consisting of cubic metal $\mathrm{Pb}$ and orthorhombic $\mathrm{PbO}_{2}$ had not changed since the second run.

In order to verify the correctness of this deduction, a metal lead sample was prepared firstly by reducing lead oxide with a mixture of $\mathrm{H}_{2}$ and $\mathrm{N}_{2}$ (volume ratio $1: 1$ ) at $300{ }^{\circ} \mathrm{C}$ for $6 \mathrm{~h}$. Figure 2 shows the XRD pattern of the reduced lead oxide sample, and both cubic metal $\mathrm{Pb}$ and orthorhombic $\mathrm{PbO}_{2}$ were observed. In Fig. $1, \mathrm{PbO}_{2}$ showed diffraction peaks at around $2 \theta=26^{\circ}(110)$ and $2 \theta=28^{\circ}$ (111) while the diffraction peak of $\mathrm{PbO}_{2}$ appeared only at around $2 \theta=28^{\circ}$ (111) in Fig. 2. This result may be caused by different treatment processes. Furthermore, the catalytic performance of $\mathrm{PbO}_{2}$, pure metal $\mathrm{Pb}$, and the metal lead sample prepared by reducing lead oxide was evaluated separately in the reaction of EC and ethanol. The results are listed in Table 2. Compared with the fresh lead oxide, the pure metal $\mathrm{Pb}$ exhibited a weak activity; $\mathrm{PbO}_{2}$ displayed a slightly lower selectivity for DEC synthesis; the prepared metal lead sample showed an excellent activity and selectivity. DEC yield decreased slightly while DEC selectivity increased over the metal lead sample. Since the prepared metal lead sample was composed of metal $\mathrm{Pb}$ and $\mathrm{PbO}_{2}$, the catalytic performance of $\mathrm{Pb} / \mathrm{PbO}_{2}$ mixture (mass ratio 1:1) prepared by physical mixing was also evaluated. DEC yield and selectivity were $13.9 \%$ and $41.9 \%$, respectively, indicating that the catalytic activity of $\mathrm{Pb} / \mathrm{PbO}_{2}$ mixture was close to that of the fresh lead oxide catalyst. Hence, we are convinced that the mixture of metal $\mathrm{Pb}$ and $\mathrm{PbO}_{2}$ is the catalytic agent and the synergistic action between metal $\mathrm{Pb}$ and $\mathrm{PbO}_{2}$ is responsible for the high catalytic activity.

From Fig. 1 we know that tetragonal $\mathrm{PbO}$ was transformed into cubic metal $\mathrm{Pb}$ during the $\mathrm{DEC}$ synthesis reaction. In order to study the reason for the reduction of $\mathrm{PbO}$ in this reaction system, the following experiments were designed 
and conducted.

Experiment No.1: the reaction of ethanol and lead oxide (reaction conditions: mass ratio of ethanol to lead oxide $=$ $60: 1,180{ }^{\circ} \mathrm{C}, 7 \mathrm{~h}$ ). Acetaldehyde and ethylacetate were detected in the liquid phase after the reaction of ethanol and the lead oxide sample. Idriss et al. [17] investigated the reaction of ethanol with a series of metal oxides and found that the main reaction products in all cases were acetaldehyde and ethylacetate. They supposed that ethanol tended to dehydrogenate to acetaldehyde which further reacted to form ethylacetate via the Tishchenko reaction. The result of the reaction between ethanol and lead oxide was in agreement with Idriss's work [17]. Furthermore, the XRD characterization of the solid sample after the reaction revealed that no metal $\mathrm{Pb}$ was observed, indicating that the presence of ethanol was not the reason for the reduction of $\mathrm{PbO}$ to metal $\mathrm{Pb}$.

Experiment No. 2: the reaction of EC and lead oxide (reaction conditions: water as solvent, mass ratio of $\mathrm{EC}$ to $\mathrm{PbO}$ $=15: 1,180{ }^{\circ} \mathrm{C}, 7 \mathrm{~h}$ ). The XRD analysis of the solid sample revealed that no metal $\mathrm{Pb}$ was observed either, indicating that the presence of EC was not the reason for the reduction of $\mathrm{PbO}$.

Experiment No. 3: the reaction of DEC and lead oxide (reaction conditions: mass ratio of $\mathrm{DEC}$ to $\mathrm{PbO}=60: 1,180$ ${ }^{\circ} \mathrm{C}, 7 \mathrm{~h}$ ). The XRD analysis of the solid sample illustrated that tetragonal $\mathrm{PbO}$ was transformed into cubic metal $\mathrm{Pb}$ (Fig. 3), indicating that the presence of DEC was the main reason for the reduction of $\mathrm{PbO}$.

To investigate the reaction of DEC and lead oxide thoroughly, the gaseous products were collected and analyzed after reaction and the results showed the presence of hydrogen, ethylene, and carbon dioxide. Furthermore, the liquid products were qualitatively analyzed by GC-MS. The result showed that besides DEC, the main products in this reaction system were ethanol, diethylether, ethylacetate, and water. Notario and coworkers [18] found that DEC could decompose to ethanol, ethylene and carbon dioxide at temperatures of $280-440{ }^{\circ} \mathrm{C}$. In our blank test, DEC did not decompose at $180{ }^{\circ} \mathrm{C}$ but did partially decompose at $180{ }^{\circ} \mathrm{C}$ in the presence of lead oxide. So we suppose that lead oxide can promote the decomposition of DEC.

Experiment No. 4: to test whether $\mathrm{PbO}$ could be reduced to metal $\mathrm{Pb}$ by the reaction products of experiment No. 3 , the reaction between lead oxide and a mixture of diethylether, ethylacetate, acetaldehyde, and ethanol in the presence of gaseous mixture of hydrogen, ethylene, carbon dioxide, and nitrogen studied (reaction conditions: mass ratio of lead oxide to diethylether to ethylacetate to acetaldehyde to ethanol $=1: 1: 1: 1: 60,180^{\circ} \mathrm{C}, 7 \mathrm{~h}$ ) was carried out. The XRD analysis of the solid sample after reaction revealed that $\mathrm{PbO}$ was not reduced to metal $\mathrm{Pb}$, indicating that the above reaction system does not effect this reduction.

Based on the above experiments, it can be inferred that the reaction between $\mathrm{DEC}$ and $\mathrm{PbO}$ is the main reason for the reduction of $\mathrm{PbO}$ to metal $\mathrm{Pb}$.

To further analyze the reason for the reduction of $\mathrm{PbO}$ to metal $\mathrm{Pb}$, experiment No. 5 was designed to test the effect of reaction time on the reaction between $\mathrm{DEC}$ and $\mathrm{PbO}$ (reaction conditions: mass ratio of DEC to lead oxide $=60: 1,180$ ${ }^{\circ} \mathrm{C}, 3 \mathrm{~h}$ ). GC analysis showed that acetaldehyde appeared at 3 $\mathrm{h}$ but disappeared at $7 \mathrm{~h}$ (experiment No. 3 ) in the reaction solution, and other products did not change at 3 and $7 \mathrm{~h}$. This means that the acetaldehyde formed must be further converted to other products such as ethylacetate [17]. Additionally, the DEC content decreased while ethanol content increased at $7 \mathrm{~h}$ in the reaction system, illustrating that prolonging the reaction time can promote the decomposition of DEC. Since acetaldehyde was detected in the reaction solution of DEC and lead oxide at the reaction time of $3 \mathrm{~h}$, we suggest that the reaction between $\mathrm{DEC}$ and $\mathrm{PbO}$ takes place as follows:

$$
\begin{gathered}
\left(\mathrm{C}_{2} \mathrm{H}_{5} \mathrm{O}\right)_{2} \mathrm{CO}+\mathrm{PbO} \longrightarrow \\
\mathrm{C}_{2} \mathrm{H}_{4}+\mathrm{CH}_{3} \mathrm{CHO}+\mathrm{CO}_{2}+\mathrm{H}_{2} \mathrm{O}+\mathrm{Pb}
\end{gathered}
$$

As mentioned above, ethanol, diethylether, ethylacetate, and hydrogen were detected in the reaction between DEC and lead oxide. We assume that ethanol can be formed by the decomposition of DEC [18], and the intermolecular dehydration of ethanol can generate diethylether [19]. Ethylacetate and hydrogen can be formed by the dehydrogenation of ethanol [20], and ethylacetate can be also produced via the Tishchenko reaction of acetaldehyde [17], as shown in the following equations:

$$
\begin{aligned}
\left(\mathrm{C}_{2} \mathrm{H}_{5} \mathrm{O}\right)_{2} \mathrm{CO} & \longrightarrow \mathrm{C}_{2} \mathrm{H}_{4}+\mathrm{C}_{2} \mathrm{H}_{5} \mathrm{OH}+\mathrm{CO}_{2} \\
2 \mathrm{C}_{2} \mathrm{H}_{5} \mathrm{OH} & \longrightarrow \mathrm{C}_{2} \mathrm{H}_{5} \mathrm{OC}_{2} \mathrm{H}_{5}+\mathrm{H}_{2} \mathrm{O} \\
2 \mathrm{C}_{2} \mathrm{H}_{5} \mathrm{OH} & \longrightarrow \mathrm{CH}_{3} \mathrm{COOC}_{2} \mathrm{H}_{5}+2 \mathrm{H}_{2} \\
2 \mathrm{CH}_{3} \mathrm{CHO} & \longrightarrow \mathrm{CH}_{3} \mathrm{COOC}_{2} \mathrm{H}_{5}
\end{aligned}
$$

In summary, the lead oxide catalyst displayed excellent stability. The recovered catalyst was found to be a mixture of cubic metal $\mathrm{Pb}$ and orthorhombic $\mathrm{PbO}_{2}$, indicating that the synergistic action between them is responsible for the high catalytic activity observed. Furthermore, tetragonal $\mathrm{PbO}$ promoted the decomposition of DEC to ethanol, ethylene, and carbon dioxide, and $\mathrm{PbO}$ itself was simultaneously reduced to metal $\mathrm{Pb}$. The catalytic mechanism of cubic metal $\mathrm{Pb}$ and orthorhombic $\mathrm{PbO}_{2}$ in the synthesis of DEC from EC and ethanol is currently under investigation.

Full-text paper available online at Elsevier ScienceDirect http://www.sciencedirect.com/science/journal/18722067 